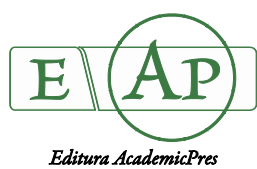

\title{
Response of ROS-Scavenging Systems to Salinity Stress in Two Different Wheat (Triticum aestivum L.) Cultivars
}

\author{
Ezatollah ESFANDIARI ${ }^{1 *}$, Gholamreza GOHARI ${ }^{2}$ \\ ${ }^{1}$ University of Maragheh, Faculty of Agriculture, Department of Agronomy and Plant Breeding, Madar Square, Maragheh, \\ Iran; esfand1977@yahoo.com (*corresponding author) \\ ${ }^{2}$ University of Maragheh, Faculty of Agriculture, Department of Horticulture, Madar Square, Maragheh, Iran; gholamreza.gohari@gmail.com
}

\begin{abstract}
Salinity leads to oxidative stress in plant cells due to increased production of reactive oxygen species. The response of two wheat (Triticum aestivum L.) cultivars, salt sensitive ('Darab2') and salt-tolerant ('Arta') were studied to salinity-induced oxidative stress $(0,75$ and $150 \mathrm{mM} \mathrm{NaCl})$. Increasing of lipid peroxidation caused oxidative stress in both sensitive and tolerant cultivars. The result showed that reactive oxygen species (ROS) viz., superoxide and hydrogen peroxide increased in leaves of 'Darab2' under salinity stress. Under salinity stress, the salt-tolerant cv. 'Arta' showed higher activity of the ROS scavenging enzymes like ascorbate peroxidase and peroxidases than 'Darab2'. Furthermore, in sensitive cv. 'Darab2' the activities of these enzymes in leaves were unable to prevent the scavenging of $\mathrm{H}_{2} \mathrm{O}_{2}$. Unlike 'Arta', there were no significant differences in superoxide dismutases and glutathione reductase activities in sensitive cv. 'Darab2' under salinity stress. The amount of reduced glutathione, reduced/oxidized glutathione ratio in leaves of 'Darab2' was lower than 'Arta' under saline conditions. It seems that in salt tolerant cultivars like 'Arta', both enzymatic and non-enzymatic ROS scavenging machineries is critical point to overcome salinity-induced oxidative stress.
\end{abstract}

Keywords: antioxidant enzymes, hydrogen peroxide, lipid peroxidation, reduced and oxidized glutathione, superoxide radical, wheat genotypes

\section{Introduction}

Wheat (Triticum aestivum $\mathrm{L}$.) is one of the most important crops in Iran, which plays a special role in people's nutrition. Abiotic stresses, such as salinity, decrease wheat growth and yield by reducing water uptake and cause nutrient disorders and ion toxicity. Salinity same as water stress, leads to oxidative stress in plant cells due to increased production of reactive oxygen species (ROS) such as superoxide radicals $\left(\mathrm{O}_{2}^{-}\right)$, hydrogen peroxide $\left(\mathrm{H}_{2} \mathrm{O}_{2}\right)$ and hydroxyl radical ( $\mathrm{HO}$ ) (Yadava et al., 2013; AbdElgawad et al., 2016; Asadi Karam and Keramat, 2017). ROS's are partially reduced forms of atmospheric oxygen, which are produced in vital processes such as photorespiration, photosynthesis and respiration. In the other word, chloroplasts, mitochondria and peroxisomes are the major sources of ROS production in plant cells (Sharma $e t$ al., 2012). ROS are highly cytotoxic and can seriously react with vital biomolecules such as lipids, proteins, nucleic acid etc., causing lipid peroxidation, protein denaturing and DNA mutation, respectively (Kaur and Zhawar, 2016). Recent evidence suggests the cell membranes are the primary effect sites in salinity stress (Bita and Gerats, 2013) because reaction of ROS and unsaturated fatty acids cause peroxidation of essential membrane lipids in plasmalemma or intracellular organelles (Bita and Gerats, 2013). Peroxidation of plasmalemma leads to the leakage of cellular contents, rapid desiccation and cell death. Intracellular membrane damage can affect respiratory activity in mitochondria, causing pigment to break down and leading to the loss of the carbon fixing ability in chloroplasts (Scandalios, 1993).

ROS generated by abiotic stresses such as salinity must be scavenged for security of essential macromolecules from destructive effects of ROS and maintenance of normal growth (Caverzan et al., 2016; Kaur and Zhawar, 2016). Superoxide dismutase (SOD: EC 1.15.1.1) is the primary scavenger, which localized in chloroplasts, mitochondria, peroxisomes and cytosol. SOD catalyses the disproportion of two $\mathrm{O}_{2}{ }^{-}$radicals to $\mathrm{H}_{2} \mathrm{O}_{2}$ and $\mathrm{O}_{2}$ (Perry et al. 2010). $\mathrm{H}_{2} \mathrm{O}_{2}$ is detoxified to two molecules of water in glutathione-ascorbate cycle by ascorbate peroxidase (APX: EC 1.11.1.11) in cooperation with dehydroascorbate reductase (DHAR: EC 1.8.5.1) and glutathione reductase (GR: EC1.6.4.2), and regenerate the ascorbic acid (Shereefa and Kumaraswamy, 2016). Moreover, catalase is the other enzyme which converts two molecules of $\mathrm{H}_{2} \mathrm{O}_{2}$ to water and oxygen (CAT: EC 1.11.1.6). It has less impact than glutathione-ascorbate cycle in $\mathrm{H}_{2} \mathrm{O}_{2}$ detoxifying 
288

(Bhutta, 2011). Changes in activities of different antioxidant enzymes under salinity were reported in wheat (Sairam $e t$ al., 2005; Bhutta, 2011), potato (Rahnama and Ebrahimzadeh, 2005), tobacco (Çelik and Atak, 2012), pea (Hernandez et al., 2000), corn (Carrasco-Ríos and Pinto, 2014) and rice (Pushpalatha et al., 2013). These reports show that the induction of ROS-scavenging enzymes, such as SOD, POD and CAT, is the most general defense mechanism of salinity tolerance for detoxifying ROS generated.

As mentioned before, salinity has the most important role in decreasing wheat yield in west and north-west of Iran. Moreover, wheat has a significant role in food security in our country. These reasons indicate the importance of research about salinity tolerance mechanisms, especially ROS scavenging systems in wheat. In this research two wheat cultivars were selected ('Arta' and 'Darab2'), which were tolerant and sensitive to salinity, respectively, to evaluate the effect of salt stress on various antioxidant enzymes activity and their relation in terms of salinity stress tolerance in differentially tolerant and sensitive wheat genotypes under hydroponic culture conditions.

\section{Materials and Methods}

\section{Plant material and salt treatments}

Two salt sensitive and salt tolerant wheat cultivars ('Darab2' and 'Arta') seeds were selected among 52 cultivars of our previous study (Shokrpour and Esfandiari, 2014). Seedlings were grown hydroponically in specifically designed plastic trays. Two seeds were placed in each hole, and then put in other rectangular plastic trays containing 2.0 L of Hoagland's solution (Hoagland and Arnon, 1950). These solutions were continuously aerated by electrical pumps (Resun, AC 9904, China) and renewed each 7 days. The experiment was carried out in an one-layer polyethylene covered greenhouse under natural sunlight.

For evaluate of different salinity levels on two cultivar of wheat, $75 \mathrm{mM}$ and $150 \mathrm{mM} \mathrm{NaCl}$ added to the solution was employed for the nourishment of related treatments. $\mathrm{pH}$ and EC of Hoagland's nutrient solutions were adjusted at 6-6.5 and $2 \mathrm{dSm}^{-1}$ by $\mathrm{HCl}$ or $\mathrm{NaOH}$ and water respectively.

Samples were obtained from 1th mature and well-expanded leaf (2nd leaf from top) and soaked in liquid nitrogen immediately. The samples were preserved in $-20^{\circ} \mathrm{C}$ until the measuring of physiological parameters.

\section{Enzyme extraction and assay}

For SOD, CAT and GPX extraction, leaf samples $(0.5 \mathrm{~g})$ were homogenized in ice-cold $0.1 \mathrm{M}$ phosphate buffer $(\mathrm{pH} 7.5)$ containing $0.5 \mathrm{mM}$ EDTA with pre-chilled pestle and mortar. Each homogenate was transferred to centrifuge tubes and was centrifuged at $4^{\circ} \mathrm{C}$ for $15 \mathrm{~min}$ at $15000 \times \mathrm{g}$. The supernatant was used for enzyme activity assay (Esfandiari et al., 2015). SOD activity was determined according to Sen Gupta $e t$ al. (1993) by measuring the inhibition of NBT (nitroblue tetrazolium) reduction at $560 \mathrm{~nm}$. One enzyme unit was defined as the amount of enzyme which could cause 50\% inhibition of the photochemical reaction. CAT and POX activities were assayed as described by Aebi (1984) and Panda et al. (2003), respectively. Method of Yoshimura et al. (2000) was employed to assay APX. GR activity was assayed according to the Sairam et al. (2005) by recording the formation of 2-nitro-5-thiobenzoic acid formation in the presence of oxidized glutathione (GSSG) and 5,5-dithio- bis-2-nitrobenzoic acid (DTNB).GSH and GSSG content were determined according to Griffith (1980). Superoxide radical content and hydrogen peroxide levels were determined according to Elstner et al. (1975) and Sergiev et al. (1997), respectively. Moreover, MDA was determined by Stewart and Bewley (1980).

\section{Statistical analysis}

All physiological and biochemical parameters were recorded with five replications. The data were analyzed by MSTATC software in the complete randomized design (CRD). Mean comparison were carried out by LSD method. Standard error of mean was also calculated for displaying in figures.

\section{Results and Discussion}

The occurrence of oxidative stress can be assessed by the amount of superoxide radicals $\left(\mathrm{O}_{2}^{-}\right)$, hydrogen peroxide $\left(\mathrm{H}_{2} \mathrm{O}_{2}\right)$ and malondialdehyde (MDA) generation under salinity conditions. Our results indicated that, production of $\mathrm{O}_{2}$ and $\mathrm{H}_{2} \mathrm{O}_{2}$ in leaves of control seedlings of 'Darab2' (sensitive cultivar) (211\% and 140\% respectively) was more than 'Arta' (tolerant cultivar) (Table 1). When salinity level increased to $75 \mathrm{mM}$ in leaves of 'Darab2', the production of $\mathrm{O}_{2}$ increased considerably, but $\mathrm{H}_{2} \mathrm{O}_{2}$ content remained unchanged. Enhancing salinity up to $150 \mathrm{mM}$, increased production of $\mathrm{ROS}\left(\mathrm{O}_{2}\right.$ and $\left.\mathrm{H}_{2} \mathrm{O}_{2}\right)$ and reached to highest level in 'Darab2' (Table 1). Unlike 'Darab2', salinity did not affected on the amount of $\mathrm{O}_{2}$ ' and $\mathrm{H}_{2} \mathrm{O}_{2}$ in 'Arta' (Table 1). The amount of $\mathrm{O}_{2}$ ' and $\mathrm{H}_{2} \mathrm{O}_{2}$ in leaves of 'Arta' at $150 \mathrm{mM}$ $\mathrm{NaCl}$ were less than 'Darab2' at control level. In other words, the content of $\mathrm{O}_{2}$ ' and $\mathrm{H}_{2} \mathrm{O}_{2}$ in 'Darab2', was about 4 and 2 times more than 'Arta' in $150 \mathrm{mM} \mathrm{NaCl}$, respectively (Table 1). According these results increasing of $\mathrm{O}_{2}^{-}$under salinity stress has been reported by Jiang and Zhang (2001), Li et al. (2004) and Kukreja et al. (2006) in corn, wheat and pea, respectively. Moreover, Bhutta (2011) and Esfandiari and Javadi (2014) have been reported that salinity stress increased of $\mathrm{H}_{2} \mathrm{O}_{2}$ level in wheat. It seems that the significant increase of $\operatorname{ROS}\left(\mathrm{O}_{2}\right.$ and $\left.\mathrm{H}_{2} \mathrm{O}_{2}\right)$ under saline conditions in 'Darab2' may play an important role in inducing oxidative and membrane permeability by attacking membrane lipids in this variety.

The present results indicate that salinity caused more severe oxidative stress in salt-sensitive cultivar in compared to salttolerant ones, as showed by generation of ROS and MDA content (Table 1). Moreover, MDA content increased in both 'Arta' and 'Darab2' cultivars but in 'Arta' there was no significant difference in MDA content between all treatments (Table 1). Sairam et al. (2005), Esfandiari and Javadi (2014), Rahmani and Padervand (2016) and Kaur and Zhawar (2016) reported that MDA content increased in salt tolerant and sensitive wheat cultivars. Although, these researchers observed that the severity of damage in cell membranes or MDA content was more in salt sensitive cultivars as compared to salt tolerant ones.

SOD activity remained unchanged with increase in salinity in 'Darab2', but its increased in 'Arta' and showed the highest activity in $150 \mathrm{mM} \mathrm{NaCl}$ (Fig. 1A). In control, the activity of SOD was 504.9 and 198.2 units g ${ }^{-1} \mathrm{FW}$ in 'Arta' and 'Darab2' respectively, which indicated that the basal level of SOD activity in 'Arta' was also significantly higher than 'Darab2' (Fig. 1A). Our results are in agreement with those of Kumar et 
Table 1. Effect of salinity on superoxide radical and peroxide hydrogen content in leaves of tolerant ('Arta') and sensitive ('Darab2') cultivars of wheat

\begin{tabular}{|c|c|c|c|c|c|c|}
\hline \multirow[t]{2}{*}{ Variant } & \multicolumn{2}{|c|}{$\begin{array}{c}\text { Superoxide radical content } \\
\left(\text { nmoles } \mathrm{g}^{-1} \mathrm{FW}\right)\end{array}$} & \multicolumn{2}{|c|}{$\begin{array}{l}\text { Hydrogen peroxide content } \\
\left(\text { mmoles } \mathrm{g}^{-1} \mathrm{FW}\right)\end{array}$} & \multicolumn{2}{|c|}{$\begin{array}{l}\text { MDA content } \\
\left(\text { nmoles } \mathrm{g}^{-1} \mathrm{FW}\right)\end{array}$} \\
\hline & 'Arta' & 'Darab2' & 'Arta' & 'Darab2' & 'Arta' & 'Darab2' \\
\hline Control & $88.7 \pm 3.85 \mathrm{e}$ & $118 \pm 16.86 \mathrm{~d}$ & $294.3 \pm 18.41 c$ & $409.3 \pm 2.99 b$ & $17.93 \pm 2.99 \mathrm{~d}$ & $37.90 \pm 1.05 c$ \\
\hline $75 \mathrm{mM} \mathrm{NaCl}$ & $105 \mathrm{~d} \pm 3.60 \mathrm{e}$ & $260 \pm 10.44 b$ & $302.4 \pm 30.07 c$ & $418.2 \pm 7.42 b$ & $19.50 \pm 2.56 \mathrm{~d}$ & $62.29 \pm 1.24 b$ \\
\hline $150 \mathrm{mM} \mathrm{NaCl}$ & $164.2 \pm 13.0 \mathrm{c}$ & $310.4 \pm 19.0 \mathrm{a}$ & $310.9 \pm 21.75 c$ & $597.2 \pm 7.23 \mathrm{a}$ & $21.23 \pm 2.01 \mathrm{~d}$ & $83.68 \pm 1.59 a$ \\
\hline
\end{tabular}

al. (2006) in Brassica juncea and Carrasco-Ríos and Pinto (2014) in corn who also observed that basal activity of SOD was higher in salt-tolerant cultivars compared to that sensitive ones. Decreasing in SOD activity in salt-sensitive cultivar and increment in salt-tolerant cultivar of wheat reported by Mandhania et al. (2006) which are according with our results. While, Bhutta (2011) have been reported that SOD activity increased in both salt sensitive and tolerant cultivars of wheat under salinity stress. It seems that the increase of SOD activity in leave of 'Arta' lead to reduced cell damage and low oxidative stress. Unlike to 'Arta', in the 'Darab2', unchanged in SOD activity may reduced the metabolic capacity of the plant, which will lead to further cell damages and cause to oxidative stress. It seems that in salt sensitive cultivar, the increasing of ROS accumulation by salinity cause to decrease of SOD activity, it could be restrict the capacity of scavenging $\mathrm{O}_{2}-$ which resulting in accumulation of ROS and ultimately led to cell membrane damage in seedling.

According to Fig. 1B the activity of CAT in the leaves of 'Arta' (8.4 units g ${ }^{-1} \mathrm{FW}$ ) was higher than 'Darab2' (4.55 units g' 1 FW) under non-salt stressed condition. There was no significant difference in CAT activity in both sensitive and tolerant cultivars at both levels of salinity in comparison to non-stressed condition. In non-stressed condition in 'Arta' the basal level activity of POX was higher than 'Darab2'. Furthermore POX activity was enhanced in both sensitive and tolerant cultivars in $75 \mathrm{mM} \mathrm{NaCl}$ (Fig. 1C). Increasing the salinity levels to $150 \mathrm{mM}$, POX activity remained unchanged in 'Darab2' but increased in 'Arta'. There were some reports that POX activity has been shown to increase in both sensitive and tolerant cultivars of wheat (Manndhania et al., 2006; Bhutta, 2011) and rice (Kumar et al., 2006). Although Esfandiari et al. (2015) have been reported that POX activity increased only in tolerant cultivars and decreased in sensitive cultivars of wheat under salinity stress.

Similar to other antioxidative enzymes, APX activity in the leaves of 'Arta' was higher than 'Darab2' under non-stressed condition and its activity enhanced by increasing salinity to 75 $\mathrm{mM} \mathrm{NaCl}$ in both cultivars (Fig. 1D). With increase of salinity levels to $150 \mathrm{mM}$, APX activity remained unchanged in 'Arta' and increased in 'Darab2'. Benavides et al. (2000) reported that the level of APX activity in salt tolerant potato clones more than sensitive clone, however in present research the activity of this enzyme in 'Arta' was more than 'Darab2' about 2.5 times. Furthermore the activity of POX and APX enhanced in both cultivars under salinity stress but it was more evidence in 'Darab2', on the other hand in 'Arta' the basal levels activity of theses enzymes were multifold higher than 'Darab2', which may have result in faster depletion of $\mathrm{H}_{2} \mathrm{O}_{2}$ in 'Arta'. Rahnema and Ebrahimzadeh (2005) reported that APX activity increased in salt-sensitive variety of potato under salinity stress. Esfandiari et al. (20115) reported that the increasing of APX in salt tolerant cultivars of wheat was more than sensitive cultivars. Amor et al. (2007) and Esfandiari and Javadi (2014) suggested that, APX activity by detoxifying $\mathrm{H}_{2} \mathrm{O}_{2}$ which generated in upon exposure of plants to saline conditions, lead to increase of plant resistance to abiotic stress.

GR Activity declined in 'Darab2' (approximately 49\% and $42 \%$ in $75 \mathrm{mM}$ and $150 \mathrm{mM} \mathrm{NaCl}$, respectively) by salinity stress. But the activity of this enzyme was increased in salinity and the highest activity was observed in $150 \mathrm{mM}$ in 'Arta' (Fig. $1 \mathrm{E})$. There were similar results in different plant such as pea (Hernandez et al., 2000) and green bean (Yaser et al., 2008) in which salt tolerance was corrected with elevated GR activity. But Çelik and Atak (2012) showed that GR activity increased in both salt-sensitive and salt-tolerant cultivars of tobacco.

With imposition of salinity treatment, activities of SOD and GR increased in leaves of 'Arta', whereas in 'Darab2', these enzymes activities remained unchanged and decreased, respectively. Although, POX and APX activities enhanced in both cultivars though CAT activity remained unchanged under salinity stress in 'Arta' and 'Darab2'. Furthermore, in 'Arta' the basal level of APX, POX and CAT were higher than 'Darab2' (Fig.1 A-E).

Glutathione is a low molecular weight antioxidant, which is a potent regulator of major cell functions. Glutathione can react directly with $\mathrm{ROS}$ such as $\mathrm{O}_{2}^{-}$and $\mathrm{H}_{2} \mathrm{O}_{2}$ and prevent inactivation of enzymes due to oxidation of essential thiol groups (Griffith, 1980). In 'Arta', the analysis of GSH content in leaves, showed a linear increase in GSH with increasing salinity level approximately 2 and 4 folds in $75 \mathrm{mM}$ and 150 $\mathrm{mM} \mathrm{NaCl}$, respectively (Table 2). However GSH content remained unchanged in 'Darab2' at both levels of salt stress (Table 2). In 'Arta', GSSG content in leaves declined linearly but its increased 'Darab2' with the increase in salinity level (Table 2). Unlike 'Arta', the ratio of GSH/GSSG decreased in 'Darab2' under salinity stress. It seems that sensitivity to salt stress could be due to reduced antioxidative capacity in detoxification of ROS. Our results are in agreement with those of Mittova et al. (2003), Vaidyanathan et al. (2003) and Meneguzzo et al. (1999) who also observed that GSH content and GSH/GSSG ratio significantly elevated in tolerant cultivars as compared to sensitive cultivars of tomato, rice and wheat respectively under salinity stress.

Table 2. Effect of salinity on reduced glutathione and oxidized glutathione content in leaves of tolerant ('Arta') and sensitive ('Darab2') cultivars of wheat.

\begin{tabular}{|c|c|c|c|c|}
\hline \multirow[t]{2}{*}{ Variant } & \multicolumn{2}{|c|}{$\begin{array}{c}\text { Reduced glutathione (GSH) } \\
\left(\text { nmoles } \mathrm{g}^{-1} \mathrm{FW}\right)\end{array}$} & \multicolumn{2}{|c|}{$\begin{array}{l}\text { Oxidized glutathione (GSSG) } \\
\left(\text { nmoles } \mathrm{g}^{-1} \mathrm{FW}\right)\end{array}$} \\
\hline & 'Arta' & 'Darab2' & 'Arta' & 'Darab2' \\
\hline Control & $2.62 \pm 0.17 c$ & $1.06 \pm 0.15 c$ & $2.18 \pm 0.21 b$ & $1.50 \pm 0.12 \mathrm{~d}$ \\
\hline $75 \mathrm{mM} \mathrm{NaCl}$ & $5.67 \pm 0.44 b$ & $2.77 \pm 0.13 c$ & $1.92 b \pm 0.13 c$ & $2.63 \pm 0.17 \mathrm{a}$ \\
\hline $150 \mathrm{mM} \mathrm{NaCl}$ & $10.54 \pm 0.56 a$ & $2.66 \pm 0.16 c$ & $1.75 \pm 0.11 \mathrm{~cd}$ & $2.79 \pm 0.13 \mathrm{a}$ \\
\hline
\end{tabular}



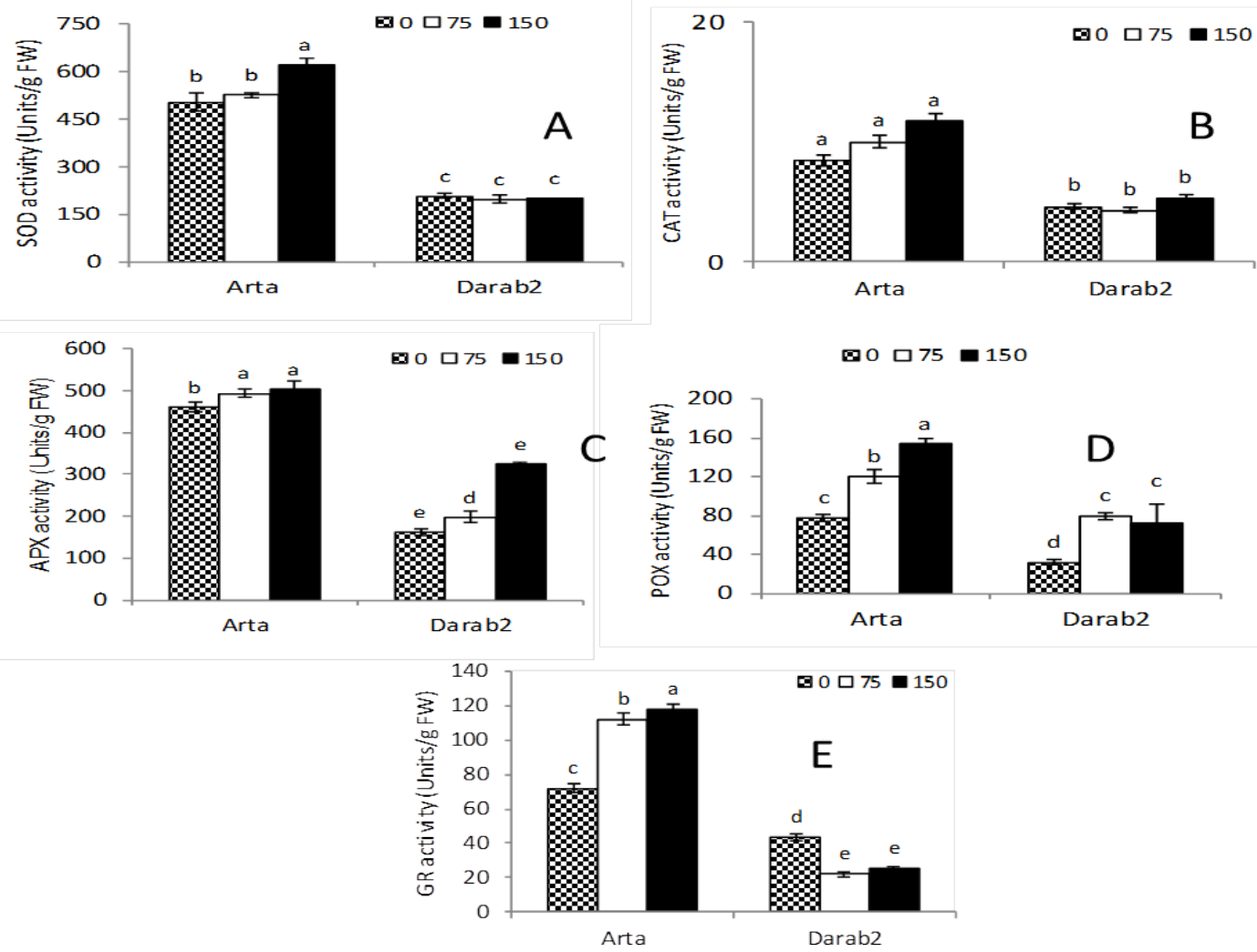

Fig. 1. Effect of salinity on antioxidant enzymes activity in leaves of tolerant ('Arta') and sensitive ('Darab2') cultivars of wheat. (A) Superoxide diamutase, (B) Catalase, (C) Ascorbate peroxidase, (D) Peroxidases, (E) Glutathione reductase

\section{Conclusions}

To avoid the negative effects of ROS and prevent to occurrence oxidative stress and damage to biomolecules, the existence of balance between the production of ROS and ROSscavenging mechanisms is necessary. Finally, the activities of antioxidant enzymes such as SOD, APX, POX and GR by high GSH/GSSG ratio increased in 'Arta' under salinity stress which led to scavenging of ROS and finally, this cultivar could be decrease the negative effects of ROS and it would be a tolerant cultivar under salinity stress.

\section{References}

AbdFlgawad H, Zinta G, Hegab M, Pandey R, Asard H, Abuelsoud W (2016). High salinity induces different oxidative stress and antioxidant responses in maize seedling organs. Frontiers of Plant Science 24:134 141.

Aebi H(1984).Catalase in vitro. Methods in Enzymology 105(1):121-126. Amor NB, Jimenez A, Megdiche W, Lundquist M, Sevilla F, Abdelly C

(2007). Kinetics of the antioxidant response to salinity in the halophyte Cakilemaritime. Journal of Integrative Plant Biology 49:982-992.

Asadi Karam E, Keramat B (2017). Foliar spray of triacontanol improves growth by alleviating oxidative damage in coriander under salinity. Indian Journal of Plant Physiology 22:120-124.

Benavides MP, Marconi PL, Gallego SM, Comba ME, Tomaro ML (2000). Relationship between antioxidant defence systems and salt tolerance in Solanum tuberosum. Australian Journal of Plant Physiology 27:273-278.
Bhutta WM (2011). Antioxidant activity of enzymatic system of two different wheat (Triticum aestivum $\mathrm{L}$ ) cultivars growing under salt stress. Plant, Soil and Environment 57(3):101-107.

Bita CE, Gerats T (2013). Plant tolerance to high temperature in a changing environment: scientific fundamentals and production of heat stresstolerant crops. Frontiers in Plant Science 4:1-18.

Carrasco-Ríos L, Pinto M (2014).Effect of salt stress on antioxidant enzymes and lipid peroxidation in leaves in two contrasting corn, 'Lluteño' and 'Jubilee'. Chilean Journal of Agricultural Research 74:89-95.

Caverzan A, Casassola A, Brammer SP (2016). Antioxidant responses of wheat plants under stress. Genetics and Molecular Biology 39:1-6.

Çelik Ö, Atak Ç (2012). The effect of salt stress on antioxidative enzymes and proline content of two Turkish tobacco varieties. Turkish Journal of Biology 36:339-356.

Elstner EF, Stoffer C, Heupel A (1975). Determination of superoxide free radical ion and hydrogen peroxide as products of photosynthetic oxygen reduction. Naturforsch 30:53-56.

Esfandiari E, Enayati V, Pourmohammad A (2015). Some physiological and bichemical traits of two wheat cultivars subjected to salinity stress. YYÜ Tarim Bilimleri Dergisi 25:221-230.

Esfandiari E, Javadi A (2014). Role of scavenging enzymes and hydrogen peroxide and gutathione $S$-transferase in mitigating the salinity effects on wheat (in Persian). Iranian Journal of Plant Biology 6:1-16.

Griffith OW (1980). Determination of glutathione disulphide using glutathione reductase and 2-vinylpyridine. Analytical Biochemistry 106(1):207-12. 
Hernandez JA, Jimenez A, Mullineaux P, Sevilla F (2000). Tolerance to pea (Pisum sativum $\mathrm{L}$ ) to long term salt stress is associated with induction of antioxidant defences. Plant, Soil and Environment 23:853-862.

Hoagland DR, Arnon DI (1950). The water culture method for growing plants without soil. California Agricultural Experiment Station Circular, No.347. Berkeley, CA: University ofCalifornia

Jiang M, Zhang J (2001). Effect of abscisic acid on active oxygen species, antioxidative defence system and oxidative damage in leaves of maize seedlings. Plant Cell Physiology 42:1265-1273.

Kaur L, Zhawar VK (2016). Antioxidant parameters under salt stress in drought tolerant and susceptible wheat cultivars. Indian Journal of Plant Physiology 21:101-106.

Kukreja S, Nandwal AS, Kumar N, Sharma SK, Kundu BS, Unvi V, Sharma PK (2006). Response of chickpea roots to short-term salinization and desalinization: Plant water status, ethylene evolution, antioxidant activity and membrane integrity. Physiology and Molecular Biology of Plants 12:67-73.

Kumar M, Jain S, Jain V (2006). Effect of $\mathrm{NaCl}$ stress on osmotic adjustment, ionic homeostats and yield attributes in salt-sensitive curd salt-resistant cultivars of Brassica juncea L. Physiology and Molecular Biology of Plants 12:75-79.

$\mathrm{Li} \mathrm{C}$, Jiao J, Wang G (2004). The important roles of reactive oxygen species in the relationship between ethylene and polyamines in leaves of spring wheat seedlings under root osmotic stress. Plant Science 166:303-315.

Mandhania S, Madan S, Sawhney V (2006). Antioxidant defense mechanism under salt stress in wheat seedlings. Biologia Plantarum 50:227-231.

Meneguzzo S, Navari-Izzo F, Izzo R (1999). Antioxidative responses of shoots and roots of wheat to increasing $\mathrm{NaCl}$ concentration. Journal of Plant Physiology 155:274280.

Mittova V, Theodoulou FL, Kiddle G, Gomez L, Volokita M, Tal M, Foyer $\mathrm{CH}, \mathrm{Guy} \mathrm{M}$ (2003). Coordinate induction of glutathione biosynthesis and glutathione-metabolizing enzymes is correlated with salt tolerance in tomato. FEBSLetters 554:417-421.

Panda SK, Singha LB, Khan MH (2003). Does aluminum phytotoxicity induce oxidative stress in green gram (Vigna radiata)?. Bulgarian Journal of Plant Physiology 29:77-86.

Perry JJP, Shin DS, Getzoff ED, Tainer JA (2010). The structural biochemistry of the superoxide dismutases. Biochemica et Biophysica Acta 1804:245-262.

Pushpalatha G, Subrahmanyam D, Sreenu K, Ram T, Subbarao V, Parma $B$, Giri A, Sarla N, Rai V (2013). Effect of salt stress on seedling growth and antioxidant enzymes in two contrasting rice introgression lines. Indian Journal of Plant Physiology 18:360-366.
Rahmani F, Padervand A (2016). Differential response to physiological drought stress in tolerant and susceptible cultivars of canola Indian Journal of Plant Physiology 21:333-340.

Rahnama $\mathrm{H}$,Ebrahimzadeh $\mathrm{H}$ (2005). The effect of $\mathrm{NaCl}$ on antioxidant enzyme activities in potato seedlings. Biologia Plantarum 49:93-97.

Sairam RK, Srivastava GC, Agarwal S, Meena RC (2005). Differences in antioxidant activity in response to salinity stress in tolerant and susceptible wheat genotypes. Biologia Plantarum 49:85-91.

Sen Gupta A, Webb RP, Holaday AS, Allen RD (1993). Overexpression of superoxide dismutase protects plants from oxidative stress. Plant Physiology 103:1067-1073.

Sergiev I, Alexieva V, Karanov E (1997). Effect of spermine, atrazine and combination between them on some endogenous protective systems and stress markers in plants. Comptes Rendus de l'Academie Bulgare des Sciences 51:121-124.

Sharma P, Jha AB, Dubey R, Pessarkli M (2012). Reactive oxygen species, oxidative damage, and antioxidative defense mechanism in plants under stressful conditions. Journal of Botany 2012:1-26.

Shereefa LA, Kumaraswamy M (2016). Reactive oxygen species and ascorbate-glutathione interplay in signaling and stress responses in Sesamum orientale L. against Alternaria sesami(Kawamura) Mohanty and Behera. Journal of Saudi Society of Agricultural Science 15:48-56.

Shokrpour M, Esfandiari E (2014). Grouping different wheat varieties for salt tolerance using some biochemical and physiological indices (in Persian).Journal ofCrop Breeding 6:53-66.

Stewart RRC, Bewley JD (1980). Lipid peroxidation associated with accelerated aging of soybean axes. Plant Physiology 65:245-258.

Vaidyanathan H, Sivakumar P, Chakrabarty R, Thomas G (2003). Scavenging of reactive oxygen species in $\mathrm{NaCl}$-stressed rice (Oryza sativa L.) differential response in salt-tolerant and sensitive varieties. Plant Science 165:1411-1418.

Yadava P, Kaur P, Singh I (2013). Exogenous application of ascorbic acid alleviates oxidative stress in maize. Indian Journal of Plant Physiology 18:339-343.

Yaser F, Ellialtioglu S, Yildiz K (2008). Effect of salt stress on antioxidant defense systems, lipid peroxidation, and chlorophyll content in green bean. Russian Journal of Plant Physiology 55:869-873.

Yoshimura K, Yabute Y, Ishikawa T, Shigeoka S (2000). Expression of spinach ascorbate peroxidase isoenzymes in response to oxidative stresses. Plant Physiology 123:223-233. 